\title{
Evidence of Improving Yield and Morphological Attributes via Half-Sib Family Recurrent Selection in Maize
}

\author{
Muhammad Noor ${ }^{1 *}$, Hidayatur Rahman ${ }^{1}$, Muhammad Iqbal ${ }^{2}$, \\ Irfan Ahmed Shah ${ }^{2}$, Ihteramullah ${ }^{1}$, Durrishahwar $^{3}$ and Farhan $\mathrm{Ali}^{2^{*}}$ \\ ${ }^{1}$ Department of Plant Breeding and Genetics, the University of Agriculture, Peshawar, \\ Pakistan. \\ ${ }^{2}$ Cereal Crops Research Institute, Pirsabak, Nowshera, Khyber Pakhtunkhwa, Pakistan. \\ ${ }^{3}$ Department of Plant Breeding and Genetics, the University of Swabi, Pakistan.
}

Authors' contributions

This work was carried out in collaboration between all authors. Authors MN, HR and MI designed the study, manage the experimental material and wrote the first draft of the manuscript. Authors IAS, I, D and FA inter the data in Microsoft excel and analyze it statistically. All authors read and approved the final manuscript.

Research Article

Received $26^{\text {th }}$ December 2012 Accepted $8^{\text {th }}$ April 2013 Published $7^{\text {th }}$ May 2013

\section{ABSTRACT}

Grain yield is a complex phenomenon which results from the interaction of various contributing factors highly influenced by different selection procedures. Recurrent selection is vital selection method for improving morphological and yield related attributes in maize crop. Half-sib families (HS) were generated from the most adapted maize variety "Pahari" at Cereal Crop Research Institute, CCRI Pakistan with the objective to improve its yield in 2009 and 2010, respectively. All the HS families were detassled well before pollen shedding to avoid any kind of selfing. At maturity, each family was harvested and shelled separately for evaluation in the respective years. $12 \times 12$ and $11 \times 11$, Partial balanced lattice square design were used during summer crop seasons 2009 and 2010, respectively at The University of Agriculture, Peshawar Pakistan. Results revealed significant differences in both cycle among families for all traits. High heritability $(0.74)$ was observed for grain yield in $\mathrm{C}_{0}$, while moderate heritability $(0.45)$ was recorded for kernel rows ear ${ }^{1}$ in 
$\mathrm{C}_{1}$. Selection differential was quite reasonable and varied according to the traits of interest. Observed response (815.74) was greater for grain yield in $\mathrm{C}_{0}$ than the expected response (681.76). Negative value of gain cycle ${ }^{-1}$ for plant height and ear height showed a declining trend, while positive value for grain yield validated selection for high yield. Regression of all the morphological and yield related traits were calculated based on the selected individuals in each cycle. Highly significant positive correlation was observed among grain yield with all the traits under investigation.

Keywords: Half-sib recurrent selection; maize, heritability; correlation; expected response and observe response.

\section{INTRODUCTION}

Maize (Zea mays L.), the sole cultivated member of genus Zea and tribe Maydeae, ranks as one of the three essential cereal crops in the world after wheat and rice. It has been determined that more than half of the increased demand in the world's food in term of cereals as a whole will be produced from maize farmers and consumers [40]. Maize is the major staple food in many countries of Latin America and Africa and is used as a fodder crop in different parts of the world. Being a major source of staple food in Africa, increasing maize productivity is a key priority for African agricultural development to diminish poverty and hunger in this region and thus a cornerstone of the proposed African Green Revolution [14]. About two third of the total world production of maize is used for livestock feed or for commercial starch and oil production. It has a great nutritional value as it contains about $66.7 \%$ starch, $10 \%$ protein, $4.8 \%$ oil, $8.5 \%$ fiber, $3 \%$ sugar and $7 \%$ ash [11].

Maize yield in most of the developing country is extremely low while it has been estimated that the expected 9 billion people in the world will require $70 \%$ more food by 2050 than today's population. A huge proportion of this increased demand will come from developing countries [40]. One of the reasons for low maize production in developing countries is the unavailability of high yielding hybrids and varieties. The obligatory increase in maize production requires substantial changes in agronomic practices and approaches of genetic improvement. However, a hazard is that these improved yields will come at a high environmental cost due to over-application of synthetic fertilizers, which cannot be sustained [37]. Furthermore, adaptation of new technologies among the farmers is a big issue to be solved by a convincing and easiest way by the breeding community. In any recurrent selection program, progress from selection is directly related to the expected change in allelic frequency and the magnitude of genetic variance in breeding population [15]. Therefore, population improvement through recurrent methodology focuses on two main objectives, first the improvement of mean performance of population though an increase in the frequency of favorable alleles and secondly, maintenance adequate genetic variability in the improved population for continued selection and genetic improvement in subsequent generations [1]. Evaluation of recurrent selection (RS) programs can lead to increased knowledge about the basic ideas and support for better management of breeding programs [14] in the under developed countries. Realized progress with any breeding scheme, however, depends largely upon the ability of the breeders to identify superior genotypes and the precision of experimentation [19]. The $S_{1}$ progeny selection and half-sib family selection are of particular interest in improving production per unit area of maize crop in the last few decades [5].

The ultimate goal of all breeding scheme is improvement of yield in one way or the other. [34] summarized results of several diverse population improvement programs involving different 
populations and selection methods. They found an average gain cycle ${ }^{-1}$ for grain yield of 2.0, $3.1,3.4,3.8$, and $4.6 \%$ cycle $^{-1}$ for $S_{2}$ progeny, full-sib, mass selection, ear-to- row, and $\mathrm{S}_{1^{-}}$progeny selection, respectively. [13] reported a $6.5 \% \mathrm{cycle}^{-1}$ increase in grain yield for the population cross. [16] also reported a $7.0 \%$ cycle $^{-1}$ increase in yield in the population cross between lowa Stiff Stalk Synthetic (BSSS) and lowa Corn Borer Synthetic No.1 (BSCB1). [21] reported that seven cycles of half-sib family selection in BSSS increased grain yield by $3.9 \%$ cycle $^{-1}$ where as six cycles of $S_{2}$-progeny selection following seven cycles of half-sib selection gave no response.

Keeping in view the foresaid problem and adequacy of half-sib recurrent selection the present study was performed to identify superior half-sib families for high yield and yield related traits that can be used in future maize breeding programs.

\section{MATERIALS AND METHODS}

\subsection{Breeding Material}

Breeding materials used in this experiment comprised 144 and 121 half-sib (HS) families. These families were developed from maize variety "Pahari" by growing the selected HS families with composite male of selected HS families in isolation at Cereal Crops Research Institute (CCRI), Pakistan. The experiment was conducted in the Khyber Pakhtunkwa province of Pakistan, which is a sub-tropical region. Two crops of maize were obtained; one in spring and other in summer season. Pahari, an early maturing variety is the most adaptable variety in most maize growing area and is a composite of Shaheen x PS-7930 but its yield is relatively low in certain plan areas of Pakistan. It is a white, semi dent variety having medium tall stature, semi dense tassel with profused branching.

\subsection{Procedure and Field Experiment}

The twenty selected families selected from the evaluation of $144 \mathrm{HS}$ families in cycle 0 along with the composite male obtained by mixing equal amount of families were grown in isolation at CCRI and through regular visits the female families were detasseled well before pollen shedding. The detasseled HS families were allowed to be pollinated naturally by the bulk male. At physiological maturity (black layer formation at hilum of maize kernel) plants were hand harvested. HS families with maximum grain filling, ear length and good looking cob were selected. During Kharif (summer) of 2009 and 2010, HS families along with one check were evaluated in replicated trial using partially balanced lattice square design with two replications at research farm of Agricultural University Peshawar, Pakistan (AUP). Row length was kept at $5 \mathrm{~m}$ with plant to plant spacing of $0.25 \mathrm{~m}$ and row to row spacing of 0.75 $\mathrm{m}$. At 4-6 leaf stage the number of plants were reduced to one plant hill ${ }^{-1}$ through thinning to maintain population size of 53300 plants ha ${ }^{-1}$. In both seasons standard cultural practices were carried out and the field was irrigated based on the requirement of plants. Fertilizer was applied in the form of diammonium phosphate (DAP) and urea at the rate of 125 and $250 \mathrm{~kg}$ $\mathrm{ha}^{-1}$, respectively. Entire DAP was broadcasted at the time of sowing while half of urea was applied before sowing during seedbed preparation and rest was applied when plants were at knee height stage. Data were recorded on the following parameters as and when appropriate, plant height, ear height, kernel rows ear ${ }^{-1}$, ear length and grain yield $\left(\mathrm{kg} \mathrm{ha}^{-1}\right)$. 


\subsection{Grain Yield $\left(\mathrm{kg} \mathrm{ha}^{-1}\right)$}

Grain yield was calculated using fresh weight $\operatorname{plot}^{-1}$ and moisture content for all the plots using the following formula [9]:

$$
\text { Grain Yield }\left(\mathrm{kgha}^{-1}\right)(15 \% \text { G.M })=\frac{\text { Freshear weight }\left(\mathrm{kg} \mathrm{plot}^{-1}\right) \times(100-\mathrm{MC}) \times 0.8 \times 10000}{(100-15) \times \text { Area harvested }(\text { plot size })}
$$

$$
\begin{array}{ll}
\text { GM } & =\text { Grain moisture } \\
\text { MC } & =\text { Moisture content }(\%) \text { in grains at harvest. } \\
\quad 0.8 & =\text { Shelling coefficient. } \\
\text { Area plot } & =3.75 \mathrm{~m}^{2} \\
1 \text { hectare } & =10,000 \mathrm{~m}^{2} \\
15 \% & =\text { moisture content required in grain at storage. }
\end{array}
$$

\subsection{Statistical Analysis}

Analysis of variance according to randomized complete block design was computed according to format (Table A) on the data for each year and each trait [24], to derive mean squares for half-sib families using computer package 'MstatC'.

\section{Table A. ANOVA format for single cycle}

\begin{tabular}{llll}
\hline SOV & DF & MS & Expected MS \\
\hline Replication $(\mathrm{r})$ & $\mathrm{r}-1$ & & \\
Block(k) & $\mathrm{r}(\mathrm{k}-1)$ & & \\
Treatments $(\mathrm{t})$ & $\left(\mathrm{k}^{2}-1\right)$ & $\mathrm{M} 2$ & $\sigma_{\mathrm{E}}^{2}+\mathrm{r}^{2}{ }_{\mathrm{G}}$ \\
Error & $(\mathrm{k}-1)(\mathrm{rk}-\mathrm{k}-1)$ & $\mathrm{M} 1$ & $\sigma^{2}{ }_{\mathrm{E}}$ \\
\hline
\end{tabular}

Estimates of genotypic and phenotypic components were calculated from the ANOVA and were used to calculate heritability on entry mean basis [10] as:

$$
\begin{array}{ll}
\delta^{2} & =\mathrm{M} 1 \text { (Error mean squares) } \\
\delta_{\mathrm{E}}^{2}+r \delta^{2} \mathrm{G} & =\mathrm{M} 2 \text { (Genotypic/families mean squares) } \\
\delta^{2} \mathrm{G} & =\mathrm{M} 2-\mathrm{M} 1 \text { (Genotypic variance }\left(\delta^{2} \mathrm{G}\right) \\
\delta^{2} \mathrm{G}+\delta^{2}{ }_{\mathrm{E} / \mathrm{r}} & =\text { Phenotypic variance }\left(\delta^{2} \mathrm{P}\right) \\
\mathrm{h}^{2}{ }_{\mathrm{BS}} & =\text { Broad sense heritability } \\
\mathrm{h}^{2}{ }_{\mathrm{BS}} & =\delta^{2} \mathrm{~g} / \delta^{2} \mathrm{~g}+\delta^{2} \mathrm{e} \text { (Fehr, 1987) }
\end{array}
$$

Selection differential was calculated as:

$$
\begin{array}{ll}
S & =\mu H S-U \text { where on } \\
S & =\text { selection differential } \\
\mu \mathrm{HS} & =\text { Mean of selected half sib families } \\
\mu & =\text { Population mean }
\end{array}
$$

Expected response $(\mathrm{Re})$ was calculated as:

$$
\operatorname{Re}=S \times h^{2}
$$


Observed response (Ro) was calculated by subtracting population mean from the mean of the progenies of the selected $S_{1}$ families [19].

$$
\mathrm{Ro}=\mathrm{R}_{\mathrm{o}}=\mu_{\mathrm{P}}-\mu
$$

Base population at each evaluation was used as a check to find out gain from each cycle. Percent gain per selection was estimated as [18]:

$$
\begin{aligned}
& \% \text { Gain cycle }^{-1}=\frac{\left(\text { Cycle }_{1}-\text { Cycle }_{0}\right)}{\text { Cycle }_{0}} \times 100 \\
& \text { Cycle }_{0}=\text { first year of half-sib family recurrent selection. } \\
& \text { Cycle }_{1}=\text { second year of half-sib family recurrent selection. }
\end{aligned}
$$

\section{RESULTS}

\subsection{Plant Height (cm}

Analysis of variance for plant height revealed highly significant differences ( $P \leq 0.01)$ among the half sib families in both cycles. Moderate heritability was observed for plant height in both $\mathrm{C}_{0}$ and $\mathrm{C}_{1}$ (Table 1). Grand mean for plant height was 164.52 and $155.49 \mathrm{~cm}$ in $\mathrm{C}_{0}$ and $\mathrm{C}_{1}$, respectively while Selection differential and Expected Response for plant height were 5.48 $\mathrm{cm}$ and $2.61 \mathrm{~cm}$, respectively in $\mathrm{C}_{0}$. Observed response for plant height in $\mathrm{C}_{0}$ was $5.48 \mathrm{~cm}$. Similarly, in $\mathrm{C}_{1} \mathrm{~S}$ was $1.43 \mathrm{~cm}$ and $\mathrm{Re}$ was $0.70 \mathrm{~cm}$ (Table 2). Gain cycle ${ }^{-1}$ for plant height was $-5.49 \%$ and Co-efficient of variation in $\mathrm{C}_{0}$ was $7.17 \%$ and in $\mathrm{C}_{1}$ was $6.54 \%$ (Table 3).

Highly significant positive correlated for plant height was observed in $\mathrm{C}_{0}$ with ear height, ear length and grain yield, while negatively and non-significantly correlation was revealed with number of kernel rows ear $^{-1}$ (Table 3). Similarly, in $\mathrm{C}_{1}$ plant height was positively and highly significantly correlated with ear height and grain yield, while positively and non-significantly correlated with ear length and number of kernel rows ear ${ }^{-1}$.

\subsection{Ear Height (cm)}

Analysis of variance showed highly significant differences $(P \leq 0.01)$ with moderate heritability estimates for ear height (Table 1). Mean values of population and selected half-sib $(\mu \mathrm{HS})$ indicated in Table 2. Population mean $(\mu)$ for ear height was 72.02 and $68.46 \mathrm{~cm}$ and selection differential for ear height was 2.98 and $3.50 \mathrm{~cm}$ in $\mathrm{C}_{0}$ and $\mathrm{C}_{1}$, respectively. Expected response was 1.59 and $1.93 \mathrm{~cm}$ in both the cycles, respectively (Table 2). Observed response in $\mathrm{C}_{0}$ for ear height was $2.98 \mathrm{~cm}$ and $\mathrm{Gain}_{\mathrm{cycle}}{ }^{-1}$ for ear height was $4.94 \%$ (Table 2).

Ear height in $\mathrm{C}_{0}$ was positively and high significantly correlated with ear length and grain yield, although it was negatively and non-significantly correlated with kernel rows ear $^{-1}$ (Table 3). Similarly, in $\mathrm{C}_{1}$ ear height was positively and non-significantly correlated with ear length, kernel rows ear ${ }^{-1}$, whereas positive and significantly correlated with grain yield (Table 3). 
Table 1. Mean square values, heritability $\left(\mathrm{h}^{2}{ }_{\mathrm{BS}}\right)$, selection differential (S) and expected response $(\mathrm{Re})$ for different parameters observed during $C_{0}$ and $C_{1}$ in maize population

\begin{tabular}{|c|c|c|c|c|c|c|c|c|}
\hline Parameter & Mean square & & $\mathbf{h}_{\mathrm{BS}}^{2}$ & & $\mathbf{S}$ & & $\mathbf{R e}$ & \\
\hline & $\mathrm{C}_{0}$ & $\mathrm{C}_{1}$ & $\mathrm{C}_{0}$ & $\mathrm{C}_{1}$ & $\mathrm{C}_{0}$ & $\mathbf{C}_{1}$ & $\mathrm{C}_{0}$ & $\mathrm{C}_{1}$ \\
\hline Plant height & 265.33 & 213.00 & 0.48 & 0.49 & 5.48 & 1.43 & 2.61 & 0.70 \\
\hline Ear height & $198.65^{x \times}$ & $102.21^{*}$ & 0.53 & 0.55 & 2.98 & 3.50 & 1.59 & 1.93 \\
\hline Kernel Rows & $1.88^{*}$ & $3.27^{x}$ & 0.63 & 0.45 & 0.86 & -1.19 & 0.17 & -0.54 \\
\hline Ear length & $3.09^{x}$ & $4.55^{\times \pi}$ & 0.67 & 0.53 & 0.25 & 6.48 & 0.54 & 3.44 \\
\hline Grain yield & $1274827.78^{\text {xx }}$ & $676804.11^{1 \times}$ & 0.74 & 0.64 & 927.22 & 639.84 & 681.76 & 410.20 \\
\hline
\end{tabular}

\subsection{Number of Kernel Rows Ear ${ }^{-1}$}

Table 1 revealed significant variation $(P \leq 0.05)$ for number of kernel rows ear $^{-1}$ in $C_{0}$, while highly significant differences $(P \leq 0.01)$ in $C_{1}$. Heritability estimates for number of kernel rows ear $^{-1}$ were 0.63 and 0.45 in $C_{0}$ and $C_{1}$, respectively (Table 1 ). Population-mean $(\mu)$ and

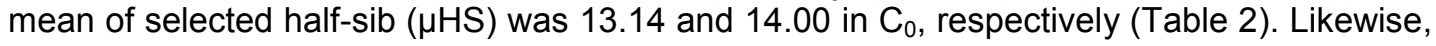
in $\mathrm{C}_{1}$ population mean was 18.17 and mean of selected half-sib was 16.98 (Table 2). Selection differential of 0.86 and expected response of 0.17 was divulged during $\mathrm{C}_{0}$ (Table 2). Similarly, in $C_{1}$ selection differential was -1.19 and expected response was -0.54 (Table 2). Observed response of 0.86 was observed for number of kernel rows ear ${ }^{-1}$ in $C_{0}$ (Table 2). Gain cycle ${ }^{-1}$ for number kernel rows ear ${ }^{-1}$ was $38.28 \%$. Co-efficient of variation was $9.02 \%$ and $7.23 \%$ in $\mathrm{C}_{0}$ and $\mathrm{C}_{1}$, respectively. Number of kernel rows ear ${ }^{-1}$ was positively and highly significantly correlated with grain yield in both $\mathrm{C}_{0}$ and $\mathrm{C}_{1}$ (Table 3 ).

\subsection{Ear Length $(\mathrm{cm})$}

Analysis of variance disclosed significant differences $(P \leq 0.05)$ among the half-sib for ear length in $\mathrm{C}_{0}$ and highly significant differences $(P \leq 0.01)$ in $C_{1}$ (Table 1). Heritability estimates were 0.67 and 0.53 for ear length in both $C_{0}$ and $C_{1}$, respectively (Table 1). Mean ear length of the population was $14.75 \mathrm{~cm}$ and of selected half-sib families $(\mu \mathrm{HS})$ was $15.00 \mathrm{~cm}$ for ear length in $\mathrm{C}_{0}$ (Table 2), while population mean of $16.41 \mathrm{~cm}$ and selected half-sib families $(\mu \mathrm{HS})$ mean $22.89 \mathrm{~cm}$ was revealed for ear length in $\mathrm{C}_{1}$ (Table 2). Selection differential of $0.25 \mathrm{~cm}$ and expected response of $0.54 \mathrm{~cm}$ was revealed for ear length in $\mathrm{C}_{0}$ (Table 2). Genotypic variance $(\sigma 2 \mathrm{G})$ and environmental variance $(\sigma 2 \mathrm{E})$ for ear height were 52.86 and 92.93 , respectively in C0. Similarly, in C1 genotypic variance $(\sigma 2 G)$ for ear height was 28.22 and environmental variance ( $\sigma 2 \mathrm{E})$ was 45.77 (data not shown). Observed response for ear length in $\mathrm{C}_{0}$ was $0.25 \mathrm{~cm}$ (Table 2). Both selection differential and expected response in $\mathrm{C}_{1}$ were 6.48 and $3.44 \mathrm{~cm}$, respectively (Table 2). Ear length was positively correlated with grain yield in both $\mathrm{C}_{0}$ and $\mathrm{C}_{1}$ (Table 3). Population means $14.75 \mathrm{~cm}$ and $15 \mathrm{~cm}$ was shown for ear length in $\mathrm{C} 0$ and $\mathrm{C} 1$, respectively. Maximum $(18.5 \mathrm{~cm})$ ear length was observed for HS-2 and minimum $(12 \mathrm{~cm})$ for HS-32, 77 and 20 in C0, while in $\mathrm{C} 1$ maximum $(20 \mathrm{~cm})$ was shown by HS-59 and minimum $(11 \mathrm{~cm})$ by HS-45. Variance components (genotypic and environmental variance) for ear length were 0.52 and 2.06 in $C_{0}$ and 1.21 and 2.14 in $C_{1}$, respectively. Low co-efficient of variation was observed in both $C_{0}$ and $C_{1}$ for ear length. 
Table 2. Means of population $(\mu)$, selected half-sib families $(\mu \mathrm{HS})$, Progeny $(\mu \mathrm{P})$, observed response (Ro) and gain cycle ${ }^{-1}$ for different parameters observed after two cycles $\left(C_{0}\right.$ and $\left.C_{1}\right)$ of recurrent half-sib family selection in maize

\begin{tabular}{|c|c|c|c|c|c|c|c|}
\hline Parameter & $\mu$ & & $\mu \mathrm{HS}$ & & $\mu P$ & Ro & Ga \\
\hline & $\mathrm{C}_{0}$ & $\mathrm{C}_{1}$ & $C_{0}$ & $C_{1}$ & $C_{1}$ & $\mathrm{C}_{0}$ & $(\%$ \\
\hline Plan & 164.52 & 155.49 & 170.00 & 156.92 & 170.00 & 5.48 & -5.49 \\
\hline Ear & 72.02 & 68.46 & 0 & 71.96 & 75.00 & 2.98 & -4.94 \\
\hline Kerr & 13. & 18.17 & 0 & 16 & 14 & 0.86 & 38.28 \\
\hline Ear & 14.75 & 16.41 & 15.00 & 22.89 & 15.00 & 0.25 & 11.25 \\
\hline Grain yield $\left(\mathrm{kg} \mathrm{ha}^{-1}\right)$ & 3150.61 & 3309.26 & 4077.83 & 3949.10 & 3966.00 & 815.74 & 5.05 \\
\hline
\end{tabular}

\subsection{Grain Yield (kg ha-1)}

The analysis of variance regarding grain yield revealed highly significant variations $(P \leq 0.01)$ among half-sib families in $\mathrm{C}_{0}$ and $\mathrm{C}_{1}$. Heritability of 0.74 and 0.64 was revealed for grain yield in $C_{0} \& C_{1}$, respectively (Table 1 ). Maximum grain yield in $C_{0}$ were observed for the HS51 (6932.50 kg ha-1) family showing almost double increase in the yield in comparison with the base population, followed by HS-75 (Fig.1). In $\mathrm{C}_{1}$ maximum grain yield $\left(4419.50 \mathrm{~kg} \mathrm{ha}^{-1}\right)$ was shown by HS-120 while the average yield of the base population was $3188 \mathrm{~kg} \mathrm{ha}^{-1}$ (Fig. 2). Population mean and mean of selected half-sib families for grain yield was 3150.61 and $4077.83 \mathrm{~kg} \mathrm{ha}^{-1}$ in $\mathrm{C}_{0}$, respectively, likewise in $\mathrm{C}_{1}$ population mean of $3309.26 \mathrm{~kg} \mathrm{ha}^{-1}$ and mean of selected half-sib families mean $(\mu \mathrm{HS})$ of $3949.10 \mathrm{~kg} \mathrm{ha}^{-1}$ was observed for grain yield. Selection differential and expected response for grain yield in $\mathrm{C}_{0}$ were $927.22 \mathrm{~kg} \mathrm{ha}^{-1}$ and $681.76 \mathrm{~kg} \mathrm{ha}^{-1}$ (Table 2), respectively. Similarly, in $\mathrm{C}_{1}$ selection differential was $(639.84$ $\left.\mathrm{kg} \mathrm{ha}^{-1}\right)$ and expected response $\left(410.20 \mathrm{~kg} \mathrm{ha}^{-1}\right)($ Table 2$)$. Greater observed response of $815.74 \mathrm{~kg} \mathrm{ha}^{-1}$ than the expected $681.76 \mathrm{~kg} \mathrm{ha}^{-1}$ was observed for grain yield. Gain cycle ${ }^{-1}$ observed for grain yield was $5.05 \%$ (Table 3 ). The multiple regression analysis of Grain yield with all the traits are listed in the supplementary material with complete detail for each cycle.

Table 3. Phenotypic correlation among grain yield related traits in Cycle-0 (above diagonal) and Cycle-1 (below diagonal)

\begin{tabular}{|c|c|c|c|c|c|}
\hline & $\mathbf{P H}$ & EH & KR & EL & YLD \\
\hline $\mathrm{PH}$ & - & $0.70^{* x}$ & $-0.08^{\mathrm{NS}}$ & $0.17^{* \prime}$ & $0.29^{* x}$ \\
\hline $\mathrm{EH}$ & $0.74^{\pi *}$ & - & $-0.05^{N S}$ & $0.17^{* x}$ & $0.26^{* x}$ \\
\hline $\mathrm{KR}$ & $0.10^{\mathrm{NS}}$ & $0.06^{\mathrm{NS}}$ & - & $0.03^{\mathrm{NS}}$ & $0.15^{x \times}$ \\
\hline EL & $0.07^{\mathrm{NS}}$ & $0.11^{\mathrm{NS}}$ & $0.85^{\times x}$ & 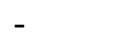 & $0.29^{x+7}$ \\
\hline YLD & $0.17^{x \pi}$ & $0.27^{\times x}$ & $0.62^{x x}$ & $0.69^{x x}$ & - \\
\hline
\end{tabular}

PH-Plant height; EH-Ear height; EL-Ear length; KR-Kernel row ear ${ }^{-1}$; YLD-Grain yield. 


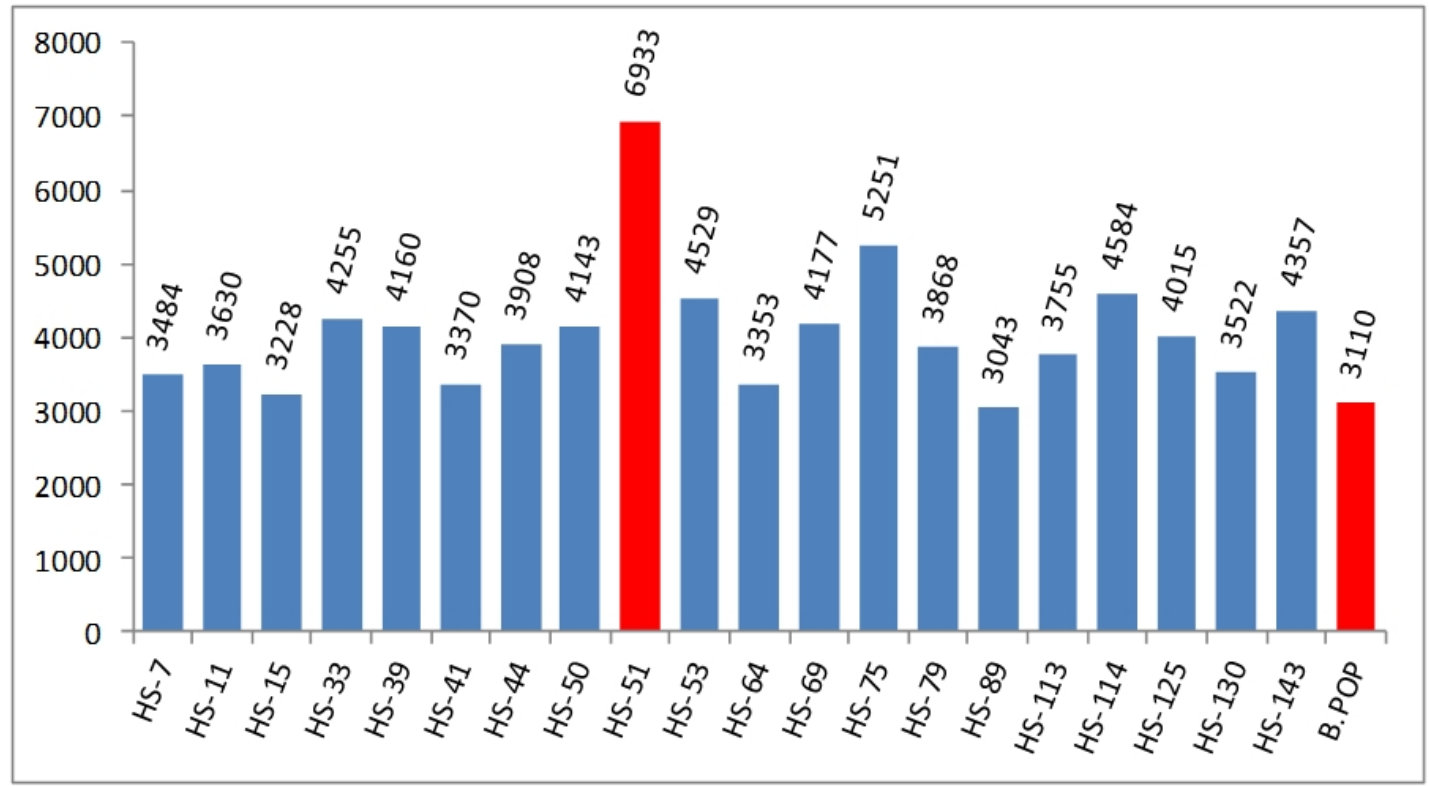

Fig. 1. Comparison of selected HS-families based on grain yield $(\mathrm{kg} / \mathrm{ha})$ with the base population (B.POP) in $\mathrm{C}_{0}$

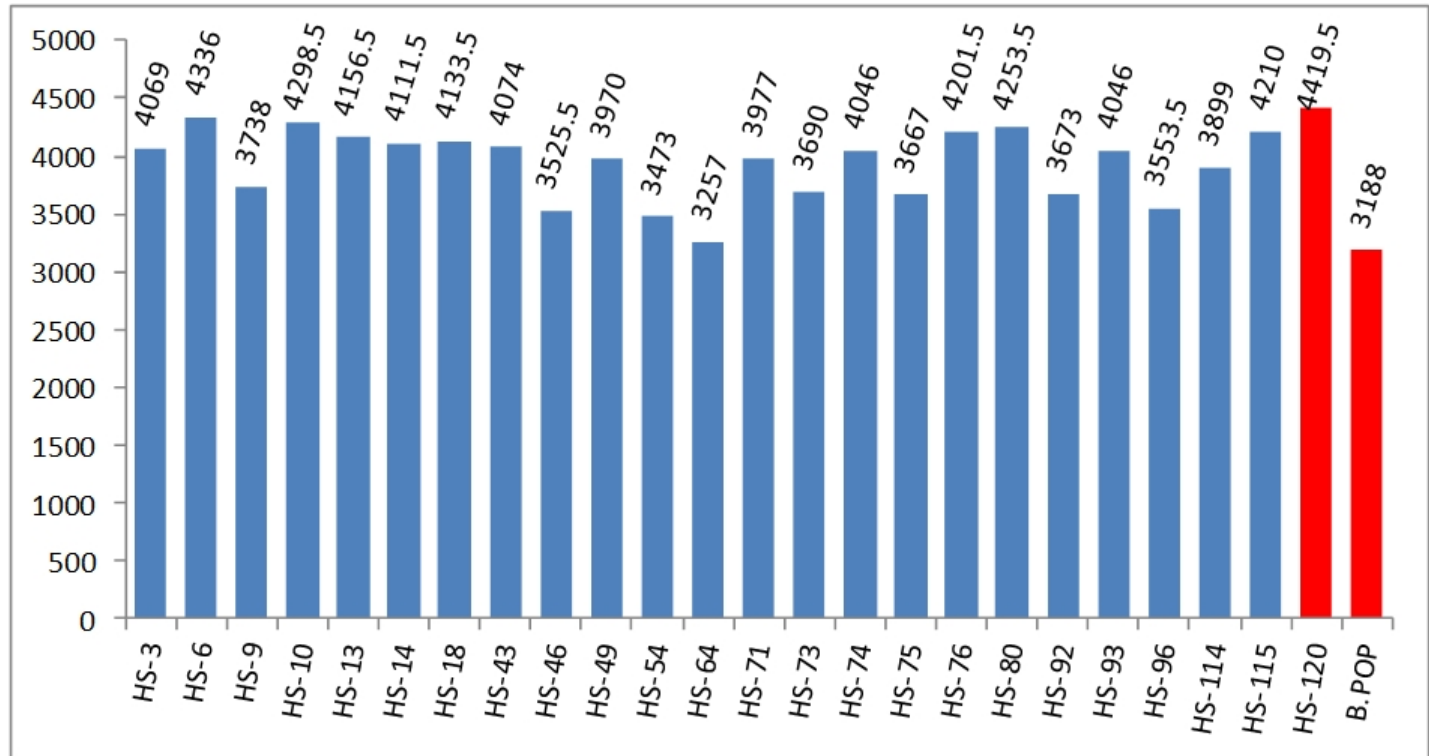

Fig. 2. Comparison of selected HS-families based on grain yield (kg/ha) with the base population (B.POP) in $\mathrm{C}_{1}$

\subsection{Supplementary Material}

Table $a, b, c$. Complete information of multiple regressions of all the studied traits with grain yield in Cycle $0\left(\mathrm{C}_{0}\right)$ 


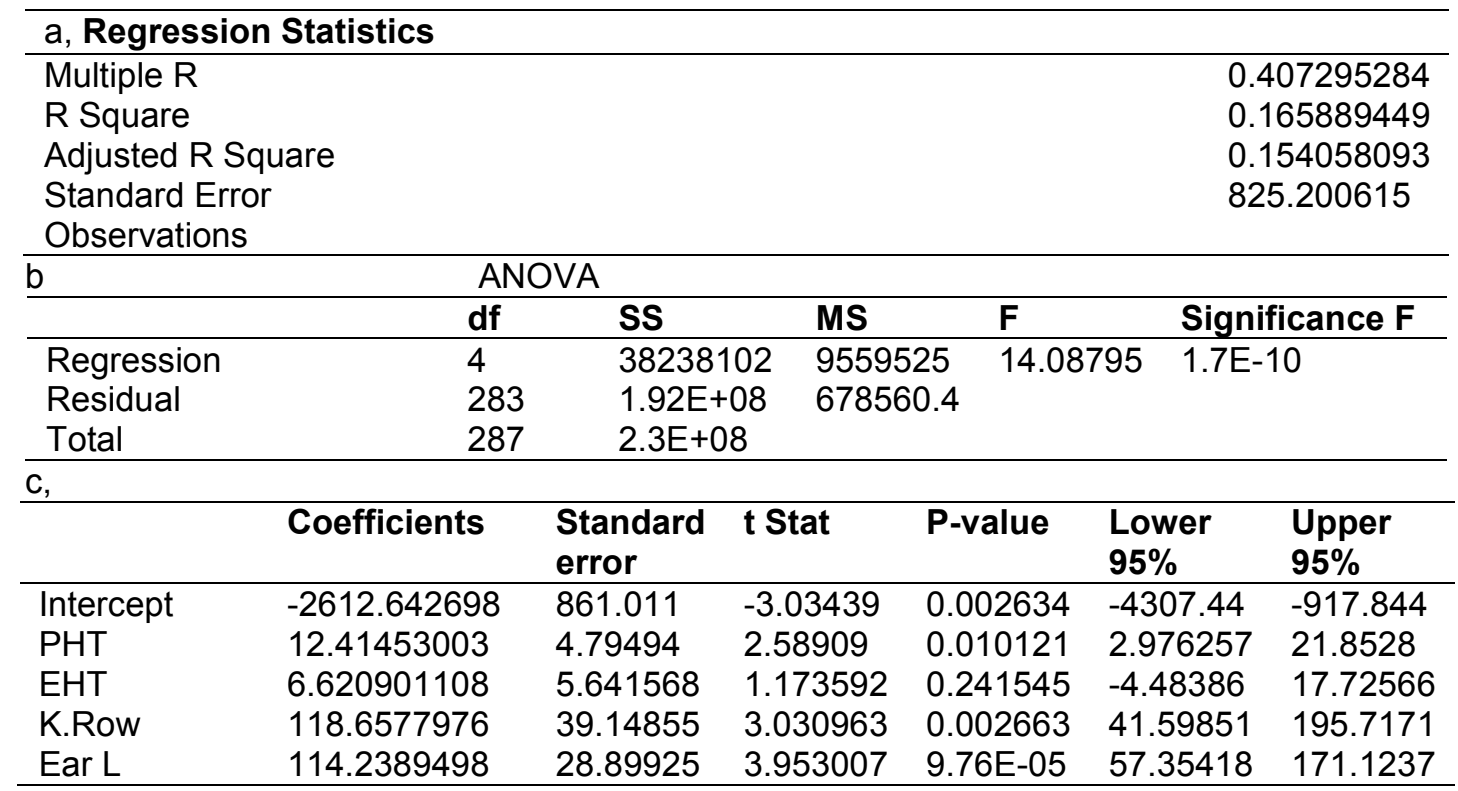

Table $d, e, f$. Complete information of multiple regression of all the studied traits with grain yield in Cycle $1\left(\mathrm{C}_{1}\right)$

Table d,

\begin{tabular}{ll}
\hline Regression statistics & \\
\hline Multiple R & 0.72869 \\
R Square & 0.530989 \\
Adjusted R Square & 0.523073 \\
Standard Error & 463.9816 \\
Observations & 242 \\
\hline
\end{tabular}

Table e,

\begin{tabular}{llllll}
\multicolumn{2}{c}{ ANOVA } & & \\
\hline & df & SS & MS & F & Significance F \\
\hline Regression & 4 & 57763383 & 14440846 & 67.07969 & $6.93 \mathrm{E}-38$ \\
Residual & 237 & 51021112 & 215279 & & \\
Total & 241 & $1.09 \mathrm{E}+08$ & & \\
\hline
\end{tabular}

Table f,

\begin{tabular}{lllllll}
\hline & Coefficients & $\begin{array}{l}\text { Standard } \\
\text { error }\end{array}$ & t Stat & P-value & $\begin{array}{l}\text { Lower } \\
\mathbf{9 5 \%}\end{array}$ & $\begin{array}{l}\text { Upper } \\
\mathbf{9 5 \%}\end{array}$ \\
\hline Intercept & -2001.41 & 485.9472 & -4.11857 & $5.27 \mathrm{E}-05$ & -2958.74 & -1044.08 \\
P.HT & -4.47013 & 3.611295 & -1.23782 & 0.217008 & -11.5845 & 2.644213 \\
E.HT & 20.72852 & 5.240472 & 3.955467 & 0.000101 & 10.40466 & 31.05237 \\
EAR L & 75.67225 & 37.07378 & 2.041126 & 0.042346 & 2.636018 & 148.7085 \\
K rows & 195.5034 & 33.12419 & 5.902136 & $1.23 \mathrm{E}-08$ & 130.248 & 260.7589 \\
\hline
\end{tabular}




\section{DISCUSSION}

\subsection{Plant Height (cm)}

Plant height is an important agronomic character which plays a vital role in plant lodging and affects grain yield. Breeders also give consideration to plant height in order to improve lodging resistance in breeding maize populations. The scientists have observed highly significant differences for plant height while conducting selection among and within half-sib families for improving the overall performance of maize crop [27] and [3]. Our results were in agreement with that of [35] who also reported highly significant differences regarding plant height after 10 cycles of full-sib recurrent selection in Nabraska Krung open pollinated maize. The heritability estimates reflected that there were optimum environmental influences on plant height. [43] reported high heritability estimates for plant height while [2] predicted low heritability for the plant height.

Low value of selection differential for plant height showed that the variety was almost stable for this character and chances for further improvement were low in one cycle. [32] reported expected response of $-4.06 \mathrm{~cm}_{\text {plant }}{ }^{-1}$ for plant height. Positive value of expected response for plant height showed that plant height can be increased up to some extent through recurrent selection. The correlation co-efficient of plant height with different traits showed the importance of improving this trait for enhancing the total yield. Plant height contributes positively to ear height, 100 grain weight and grain yield while it has no effect on the kernel rows [31]. [6] also observed positive and highly significant correlation between plant height and grain yield. Plant height was strongly associated with the flowering date, because internode formation stops at floral initiation, which means that earlier flowering maize is usually shorter [39]. Observed response for the plant height was greater than the expected one which may be to some heterosis during recombination phase. Gain cycle ${ }^{-1}$ for plant height was observed revealing that via recurrent selection improvement in the trait is possible.

\subsection{Ear Height $(\mathrm{cm})$}

Similar to the effect of plant height on lodging, ear height also has an effect on plant lodging and ultimately grain yield. Placement of ear in maize is of great importance in the production of a successful crop. If ear is placed above the middle, there is a chance to be damaged by lodging, but if it is present too low, then the wild animal can damage it, so for producing lodging resistant maize population it needs proper attention. [27] also observed highly significant differences for ear height while conducting selection among and within half-sib families in Opaque-2 maize population. Moderate heritability of the trait showed that the trait is under genetic control and further selection for ear height would be effective. [6] reported highly heritability and [3] reported low heritability for ear height during evaluation of maize 3way crosses through genetic variability, broad sense heritability, characters association and path analysis. Similarly, [31] also reported low heritability, while evaluating the genetic variability among maize cultivars.

Central or near central placement of top ear were desirable for resistance to lodging. Greater observed response was observed for ear height than the expected one during $\mathrm{C}_{0}$. As the selection was primarily practiced for yield, therefore a pronounced response was not expected for ear height. 
Ear height both in $\mathrm{C}_{0}$ and $\mathrm{C}_{1}$ was positively and highly significantly correlated with grain yield, although positively and non-significantly correlated with percent grain moisture content at harvest. Correlation between ear height and kernel rows ear ${ }^{-1}$ was negatively non-significant and positively non-significant in $\mathrm{C}_{0}$ and $\mathrm{C}_{1}$, respectively. [36] reported a correlation between earfamiliess and ear height in maize. The higher the ear is, the later the plant matures, but earfamiliess and lower ear height have no absolute reciprocal relationship. [26] found a significant correlation between plant and ear height in unselected inbred. Negative value of gain per cycle showed a declining trend for ear height as high placement of top ear results in lodging [32].

\subsection{Number of Kernel Rows Ear ${ }^{-1}$}

Number of kernel rows ear ${ }^{-1}$ along with ear length, ear diameter and grain weight contributes to the final grain yield. [23] suggested that ear girth and number of kernel rows ear ${ }^{-1}$ should be given more importance while doing selection for grain yield improvement in maize. [28] results were concurrent with the results in this experiment regarding significance level and heritability for kernel rows ear ${ }^{-1}$. Similarly, [43] also observed high heritability for kernel rows ear ${ }^{-1}$, while estimating the genetic variance in an $F_{2}$ maize population.

Number of kernel rows ear ${ }^{-1}$ was positively and significantly correlated with grain yield. [24] observed high influence of kernel row number with the total yield of maize. Gain cycle ${ }^{-1}$ for number kernel rows ear-1 was $38.28 \%$. Variance components (genotypic and environmental variance) for kernel rows ear ${ }^{-1}$ were 0.24 and 1.43 in $C_{0}$ and 0.74 and 1.79 in $C_{1}$. Low coefficient of variation was observed in both in $\mathrm{C}_{0}$ and $\mathrm{C}_{1}$.

\subsection{Ear Length (cm)}

Analysis of variance showed significant differences $(P \leq 0.05)$ for ear length in $C_{0}$ and highly significant differences $(P \leq 0.01)$ in $C_{1}$. Similar findings were reported by [20] in their experiment on "Grain and Stover yield of corn with varying times of plant density reduction". Moderate heritability estimates were observed for ear length in $C_{0}$ and $C_{1}$, respectively. [43] observed high heritability for ear length in their experiment. [20] observed low heritability for ear length during his experiment on "phenotypic diversity for morphological and agronomic traits in traditional Ethiopian highland maize accessions". Based on heritability and selection differential, expected responses for ear length were 0.54 and $3.44 \mathrm{~cm}$ in $\mathrm{C}_{0}$ and $\mathrm{C}_{1}$, respectively. Observed response for ear length in $C_{0}$ was $0.25 \mathrm{~cm}$, lower than the expected one.

Ear length in $\mathrm{C}_{0}$ was positively and non-significantly correlated with 100 grain weight, while positively and highly significantly correlated with grain yield in $C_{1}$. [25] reported a positive correlation between ear length and grain yield. Similarly, [8] also observed positive and highly significant correlation between ear length and grain yield. [21] reported negative correlation among ear length, kernel weight and kernel rows. Gain cycle ${ }^{-1}$ for ear length was $11.25 \%$, manifesting that after two cycles of half-sib recurrent selection $11.25 \%$ improvement was made for ear length.

\subsection{Grain Yield $\left(\mathrm{kg} \mathrm{ha}^{-1}\right)$}

Increased grain yield is the main objective of every plant breeding program. Procedures often used for the improvement of grain yield in maize are of four main types: mass 
selection, selection based on half sib (testcross or topcross) progeny performance, full sib progeny selection, and selfed progeny selection [16]. Grain yield in maize is the most complex character with which a plant breeder works and is controlled by other yield factors like kernels weight, kernels rows ear ${ }^{-1}$, ear length, ear diameter and prolificacy. Therefore selection for desirable genotypes should be made based on grain yield as well as other yield components which could influence the yield. Our results also confirmed the findings of [29] who reported highly significant differences for the yield components while comparing original and selected maize populations for grain yield traits. Similarly, [33] and [4] also observed highly significant differences for grain yield while evaluating maize genotypes. High heritability of 0.74 and 0.64 for grain yield was revealed in $C_{0}$ and $C_{1}$, respectively showing effective control of this trait by the genetics of maize families. [42] and [6] reported moderate heritability for half-sib and BSSSCO X BSCB1C0, respectively. Similarly [32] also observed high heritability (65.63) in $\mathrm{C}_{0}$ and low heritability (56.61) in $\mathrm{C}_{3}$. Selection differential showed that through half-sib recurrent selection we can increase the total production of maize. [42] observed 0.67 selection differential for grain yield $\left(\mathrm{Mg} \mathrm{ha}^{-1}\right)$, while comparing responses to seven methods of recurrent selection in the BS11 maize population. Expected response for the grain yield in $C_{0}$ was $681.76 \mathrm{~kg} \mathrm{ha}^{-1}$ and $410.20 \mathrm{~kg} \mathrm{ha}^{-1}$ in $\mathrm{C}_{1}$. Greater observed response for grain yield than the expected response showed the worth of selection for grain yield. [32] reported $(6.76 \%)$ expected response for grain yield $\left(\mathrm{g} \mathrm{plant}^{-1}\right)$. Gain cycle ${ }^{-1}$ observed for grain yield was $5.05 \%$, showing that after two cycles of half-sib recurrent selection grain yield was increased by $5.05 \%$. [32] also reported similar results of low co-efficient of variation $(11.92 \%)$ for grain yield. In $C_{1}$ the grain yield of all the families were almost in the same range and more or less an acceptable amount of yield can be increase after two cycles of half-sib recurrent selection. Furthermore, the stability of grain yield showed us an appropriate selection during both the cycles.

\section{CONCLUSIONS}

These results suggest that half-sib family recurrent selection is the most important breeding procedure for improving the overall production of maize. The selected families can be used for further improvement of yield with the easiest method of half-sib recurrent selection.

\section{ACKNOWLEDGMENT}

I present my special thanks to prof. Dr. Farhatullah for his encouragement and providing field and other research facility to conduct the experiment.

\section{COMPETING INTERESTS}

Authors have declared that no competing interests exist.

\section{REFERENCES}

1. Ali F, Munir M, Rahman H, Noor M, Durrishahwar, Yan J, Shaukat S. Heritability estimates for yield and related traits based on testcross progeny performance of resistance maize inbred lines. J. Food Agri. Envir. 2011;9:438-443.

2. Ajala SO, Ago CE, Olaoye G. Comparison of predicted responses to three types of recurrent selection procedures for the improvement of a maize (Zea mays L.) population. J. Plant Breeding and Crop Scie. 2009;1(8):284-292. 
3. Akbar M, Shakoor MS, Hussain A, Sarwar M. Evaluation of maize 3-way crosses through genetic variability, broad sense heritability, Characters association and path analysis. J. Agric. Res. 2008;46(1):39-45.

4. Badu-Apraku B, Fakorede MAB, Lum AF. $S_{1}$ Family Selection in early-maturing maize populations in Striga-Infested and Striga-Free environments. Crop Sci. 2008;48:19841994.

5. Beavis WD, Smith OS, Grant D, Fisher R. Identification of quantitative trait loci using small sample of topcrossed and $F_{4}$ progeny from maize. Crop Sci. 1994;34:882-896.

6. Betran FJ, Hallauer AR. Characterization of inter-population genetic variability in three hybrid maize populations. J. Heredity, 1996;87(4):319-928.

7. Beyene $\mathrm{Y}$, Botha AM, Myburg AA. Phenotypic diversity for morphological and agronomic traits in traditional Ethiopian highland maize accessions. South Afric. J. Plant and Soil. 2005;22:100-105.

8. Broccoli AM, Burak R. Effect of genotype $x$ environment interactions in popcorn maize yield and grain quality. Span. J. Agric. Res. 2004;2(1):85-91.

9. Carangal VR, Ali SM, Koble AF, Rinke EH, Sentz JC. Comparison of $S_{1}$ with testcross evaluation for recurrent selection in maize. Crop Sci. 1971;11:658-661.

10. Carson ML, Stuber CW, Senior ML. Identification and mapping of quantitative trait loci conditioning resistance to southern leaf blight of maize caused by Cochliobolus herterostrophus race O. Phytopathology, 2004;94:862-867.

11. Chaudhary AH. Effect of population and control of weeds with herbicides in maize. Field crop Abst. 1983;35(5):403.

12. Ejeta G. African Green Revolution needn't be a mirage. Science, 2010;327(5967):831832.

13. Eyherabide $\mathrm{GH}$, Hallauer AR. Reciprocal full-sib selection in maize: I. Direct and Indirect responses. Crop Sci. 1991;31:952-959.

14. Guimaraes PE. Effect of long term recurrent selection program on the genetic structure of BSSS maize population. PhD. Thesis lowa State Uni. Ames lowa, USA; 2001.

15. Helms TC, Hallauer AR, Smith OS. Genetic drift and selection evaluated from recurrent selection program in maize. Crop Sci. 1989;29:602-607.

16. Horner ES, Chapman WH, Lutrick MC, Lundy HW. Comparison of selection based on yield of $\mathrm{S}_{2}$ progenies in maize. Crop Sci. 1969;9:539-543.

17. Keerantinijakal V, Lamkey KR. Response to recurrent selection in BSSS and BSCBI maize population. Crop Sci. 1993;33:73-77.

18. Kelling BI. Effect of soybeen mosaic virus on root volume and dry weight of soybean plants. Crop Sci. 1982;22:629-639.

19. Khalil IA, Rahman H, Durrishahwar, Nawaz I, Ullah H, Ali F. Response to selection for grain yield under maydis leaf blight stress environment in maize (Zea mays). Biodicon. 2010;3(1):121-127.

20. Khan K, Iqbal M, Shah Z, Ahmad B, Azim A, Sher H. Grain and Stover yield of corn with varying times of plant density reduction. Pak. J. Bio. Sci. 2003;6(19):1641-1643.

21. Lamkey KR. Fifty years of recurrent selection in the lowa stiff stalk synthetic maize population. Maydica. 1992;37:19-28.

22. Mejaya MJ, Lambert RJ. Selection response for increased grain yield in two high oil maize synthetics. Indonesian J. Agri. Sci. 2007;8(1):1-9.

23. Manivannan $\mathrm{N}$. Character association and component analysis in maize. Madras Agric. J. 1998;85:293-294.

24. Mehmood Z, Ajmal SU, Jilani G, Irfan M, Ashraf M. Genetic studies for high yield of maize in Chitral valley. Int. J. Agri. Biol. 2004;6(5):788-789. 
25. Miles JW, Dudley JW, White DG, Lambert RJ. Improving corn population for grain yield and resistance to leaf blight and stalk rot. Crop Sci. 1980;20:247-250.

26. Nemati A, Sedghi M, Sharifi RS, Seiedi MN. Investigation of correlation between traits and path analysis of corn (zea mays L.) grain yield at the climate of Ardabil Region (Northwest Iran). Not. Bot. Hort. Agrobot. Cluj. 2009;37(1):194-198.

27. Obilana AT, Hallauer AR. Estimation of variability of quantitative traits in BSSS by using unselected maize inbred families. Crop Sci. 1974;14:99-103.

28. Pommer CV, Geraldi IO. Selection among and within half-sib families in Opaque-2 maize population. Brazil J. Genetics. 1983;6(3):461-472.

29. Rafique M, Hussain A, Mahmood T, Alvi AW, Alvi MB. Heritability and interrelationships among grain yield and Yield components in maize (Zea mays L). Int. J. Agri. Biol. 2004;6(6):1113-1114.

30. Rahman H, Khalil IH, Islam N, Durrishahwar, Rafi A. Comparison of original and selected Maize populations for grain yield traits. Sarhad J. Agric. 2007;21(2):231-235.

31. Salami AE, Adegoke SAO, Adegbite OA. Genetic variability among maize cultivars grown in Ekiti-State, Nigeria. Middle-East J. Sci. Res. 2007;2(1):09-13.

32. Santos MF, Moro GV, Aguiar AM, de Souza Jr. CL. Responses to reciprocal recurrent selection and changes in genetic variability in IG-1 and IG-2 maize populations. Genet. and Mole. Biol. 2005;28(4):781-788.

33. Sharifi RS, Sedghi M, Gholipouri A. Effect of plant density on yield and yield attributes of maize hybrids. Res. J. Biol. Sci. 2009;4(4):375-379.

34. Sprague GF, Eberhart SA. Corn breeding. in G. F. Sprague (ed.) Corn and corn improvement., Am. Soc. Agron., Madison, WI. 1977;305-362.

35. Stromberg DC, Compton WG. Ten cycles of full-sib recurrent selection in maize. Crop Sci. 1989;29:1170-1172.

36. Suranyi J, Mandy GY. A kukorica. (Corn) Magyarország kultúrflórája. (Culture flora of Hungary) Akadémiai Kiadó, Budapest; 1955.

37. Robertson GP, Vitousek PM. Nitrogen in Agriculture: Balancing the Cost of an Essential Resource Annual Review of Environment and Resources. 2009;34:97-125.

38. Tanner AH, Smith OS. Comparison of half-sib and S1 recurrent selection in the krug yellow dent maize populations. Crop Sci. 1987;27:509-513.

39. Troyer AF, Larkins JR. Selection for early flowering in corn: 10 late synthetics. Crop Sci. 1985;25:695-697.

40. Yan J, Warburton M, Crouch J. Association mapping for enhancing maize (Zea mays L.) genetic improvement. Crop Sci. 2011;51(2):433-449.

41. Weyhrich RA, Lamkey KR, Hallauer AR. Responses to seven methods of recurrent selection in the BS11 maize population. Crop Sci. 1998;38:308-321.

42. Wolf DP, Peternelli LA, Hallaure RA. Estimates of genetic variance in F2 maize population. The American Genet. Assoc. 2000;91:384-391.

43. Zivanovic T, Secanski M, Filipovic M. Combining abilities for the number of kernel rows per ear in silage maize. Plant breeding and seed production, 2007;3(3-4):13-19.

(C) 2013 Noor et al.; This is an Open Access article distributed under the terms of the Creative Commons Attribution License (http://creativecommons.org/licenses/by/3.0), which permits unrestricted use, distribution, and reproduction in any medium, provided the original work is properly cited.

Peer-review history:

The peer review history for this paper can be accessed here: http://www.sciencedomain.org/review-history. php?iid=229\&id=2\&aid=1359 